\title{
LUSITANIAN SPECIES OF THE AMPHIPOD PSEUDONIPHARGUS CHEVREUX, 1901 WITH A KEY TO ALL KNOWN IBERIAN SPECIES*
}

\author{
by
}

\section{JOS NOTENBOOM}

Institute of Taxonomic Zoology, University of Amsterdam, P.O. Box 20125, 1000 HC Amsterdam, The Netherlands

\begin{abstract}
Pseudoniphargus callaicus $\mathbf{n}$. sp. is described from a well in the vicinity of the coast in northwestern Galicia, Spain. The type materials of Ps. mateusorum Stock, longispinum Stock, and brevipedunculatus Stock are reexamined and their resemblances discussed.

The new species, Ps. callaicus, appears to belong together with Ps. mateusorum and brevipedunculatus to a weakly defined Lusitanian-Azorian group. This group is more closely related to the north Spanish and Bermudian species, and to Ps. gibraltaricus from southern Spain, than to its remaining congeners.

An updated checklist and key of the Iberian Pseudoniphargus species is included in this paper.
\end{abstract}

\section{RESUMEN}

Se describe Pseudoniphargus callaicus n. sp. de un pozo situado en las cercanías de la costa, en el norte de Galícia, España. Se examina de nuevo el material típico de las especies Ps. mateusorum Stock, longispinum Stock y brevipedunculatus Stock, y se discuten las afinidades respectivas.

La nueva especie, $P$ s. callaicus, parece pertenecer a un grupo Lusitano-Azórico, cuya definición es poco marcada y del cual también formarían parte Ps. mateusorum y brevipedunculatus. Este grupo se relaciona más estrechamente con las especies del norte de España y de las Bermudas, y con Ps. gibraltaricus del sur de España, que con los restantes congéneres.

En el trabajo se incluye una liste actualizada y una clave de todas las especies ibéricas de Pseudoniphargus.

\section{INTRODUCTION}

Members of the stygobiont amphipod genus Pseudoniphargus are well represented in Iberian groundwaters. Two recent papers on their systematics showed the diversity of these

\footnotetext{
* Groundwater crustaceans of Spain, 6.
}

amphipods in the Cantabrian Mountains and Pyrenees of northern Spain (Notenboom, 1986) and the Betic Cordillera of southern Spain (Notenboom, 1987). In the present paper a new species, Ps. callaicus, from a well in the vicinity of the coast of farthermost northwestern Galicia (Spain) is described. In order to facilitate comparison of the systematics of Ps. callaicus and other Spanish species with the species from Portugal, types have been reexamined and remarks on their morphology are made.

$\mathrm{Up}$ to the present the only records of Pseudoniphargus in the western part of the Iberian Peninsula (fig. 1) were from central Portugal. From this area Stock (1980) described two new species: Ps. mateusorum from a cave in the Sierra de la Arrábida near the Bay of Setubal (just S. of Lisbon) and Ps. longispinum from wells in the surroundings of Coimbra. Furthermore, the existence of unidentified material from this area was indicated by Mateus (1980) and Stock (1980). Previously, several of these and other records from Portugal were mentioned as Ps. africanus Chevreux, 1901, by Schellenberg (1943), Mateus \& Mateus (1978), and Mateus (1980).

The fauna of subterranean waters of Portugal is rather well explored. In particular, previous investigations have revealed a rich and endemic fauna of stygobiont asellid isopods (see Afonso, 1983, 1984 a \& b; Henry, 1983). Stygobiont amphipods are recorded as well (see for review Mateus \& Mateus, 1978, and Mateus, 1980); however, they are not as thoroughly studied as the asellids. Pseudoniphargus has been recorded from the central-western part of the country only, in contrast to other stygobiont amphipod genera which seem to be distributed in other 


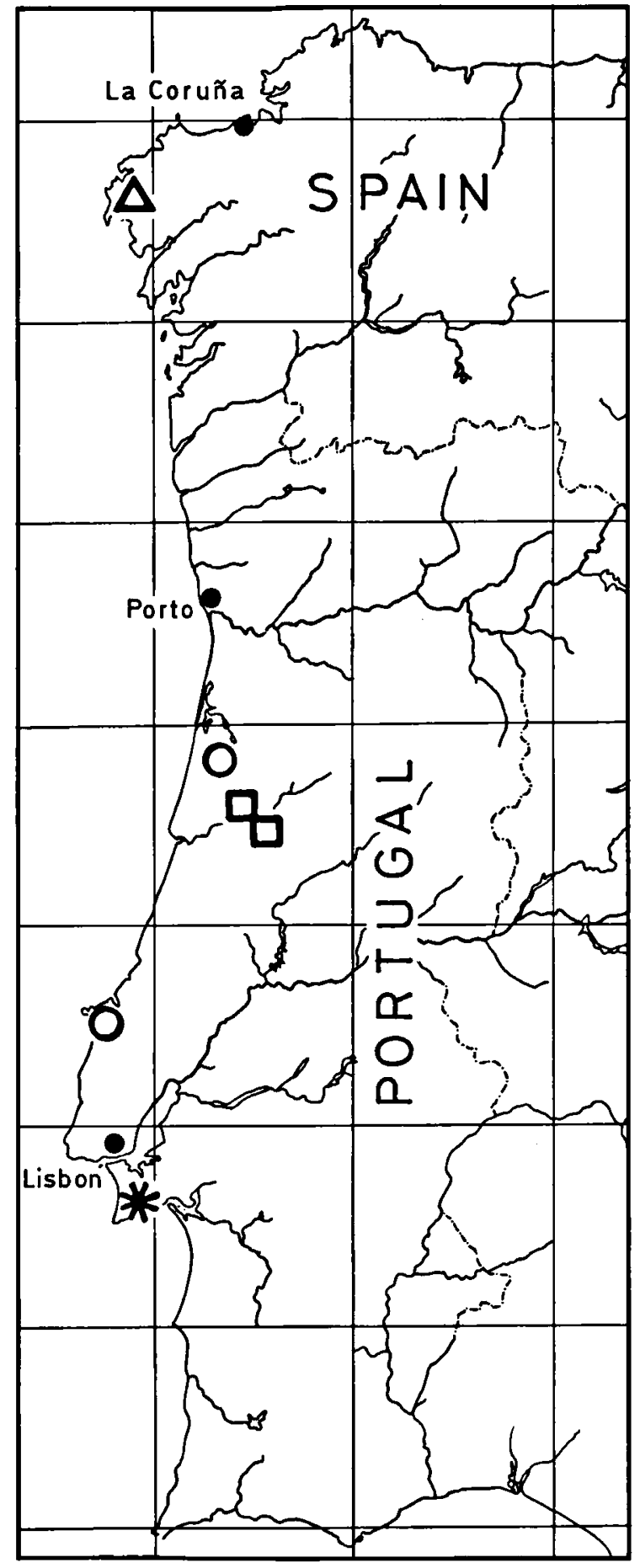

Fig. 1. Map of the western Iberian Peninsula showing the distribution of Pseudoniphargus: $\triangle P$ s. callaicus n. sp.; $\star P s$. maleusorum Stock, 1980; $\square$ Ps. longispinum Stock, 1980; O unidentified materials indicated by Stock (1980) and Mateus (1980). Map provided with universal transverse mercator (UTM) grid, each square represents $100 \times 100$ km.
Portuguese regions as well. In particular the genus Haploginglymus is mentioned as widely distributed in the north and south of the country.

With exception of Ps. callaicus from N.W. Spain, all other species of Pseudoniphargus proved to be distributed in areas covered by Late Cretaceous and Tertiary marine sediments, although the latter are more common. Thus, these continental areas at the present time were obviously part of the marine environment during earlier eras. The locality of Ps. callaicus belongs to the ancient crystalline basement of the peninsula not subjected to important marine transgressions since the Paleozoic. However, local marine transgressions during younger eras cannot be excluded in the coastal area where Ps. callaicus has been found.

Recent systematic studies of Iberian Pseudoniphargus have significantly increased the number of species recognized. To facilitate the accessibility of this fauna for other workers, a key and checklist are included at the end of the present paper.

\section{DESCRIPTION OF THE NEW SPECIES}

\section{Pseudoniphargus callaicus n. sp.}

(Figs. 2-4)

Material examined. - Spain, prov. La Coruña, well along the road to Xaviña, $1 \mathrm{~km}$ from Camariñas $(=60 \mathrm{~km}$ N.W. of Santiago de Compostela), UTM coordinates MH8475, alt. about sea level; 17 Sept. 1986 (sta. 86-9/2), $1 \%$ holotype, 1 damaged $O$ allotype, and $4 \% \bigcirc$ paratypes, leg. R. Leys \& K. Hogendoorn (Zoölogisch Museum Amsterdam coll. no. Amph. 108.283). Accompanying fauna: asellid isopods.

Description. - Largest female $6.0 \mathrm{~mm}$ (holotype), paratypes ranging from 5.0 to 5.5 $\mathrm{mm}$, no ovigerous females present, holotype and 2 paratypes with setose oostegites. Single male (allotype) slightly damaged, probably subadult.

Female: Antenna 1 (fig. 2a) about half of body length; peduncle segment 1 and 2 of same length, segment 3 about $2 / 3$ of length of seg- 


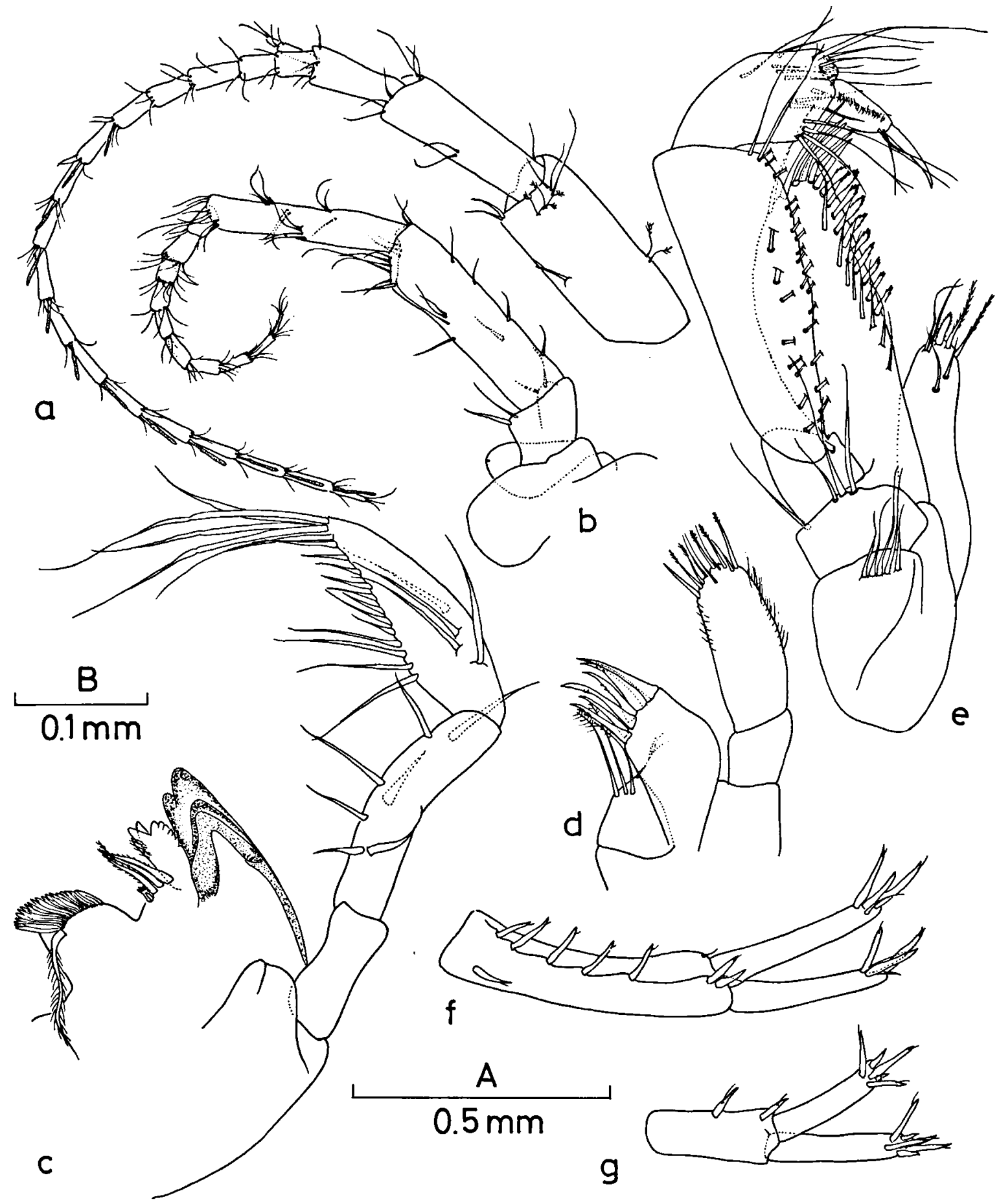

Fig. 2. Pseudoniphargus callaicus $\mathrm{n}$. sp., $\$$ paratype $6.0 \mathrm{~mm}$ : a, antenna 1 (scale A); b, antenna 2 (A); c, left mandible (C); d, maxilla 1 (B); e, maxilliped (B); f, uropod 1 (A); g, uropod 2 (A). 


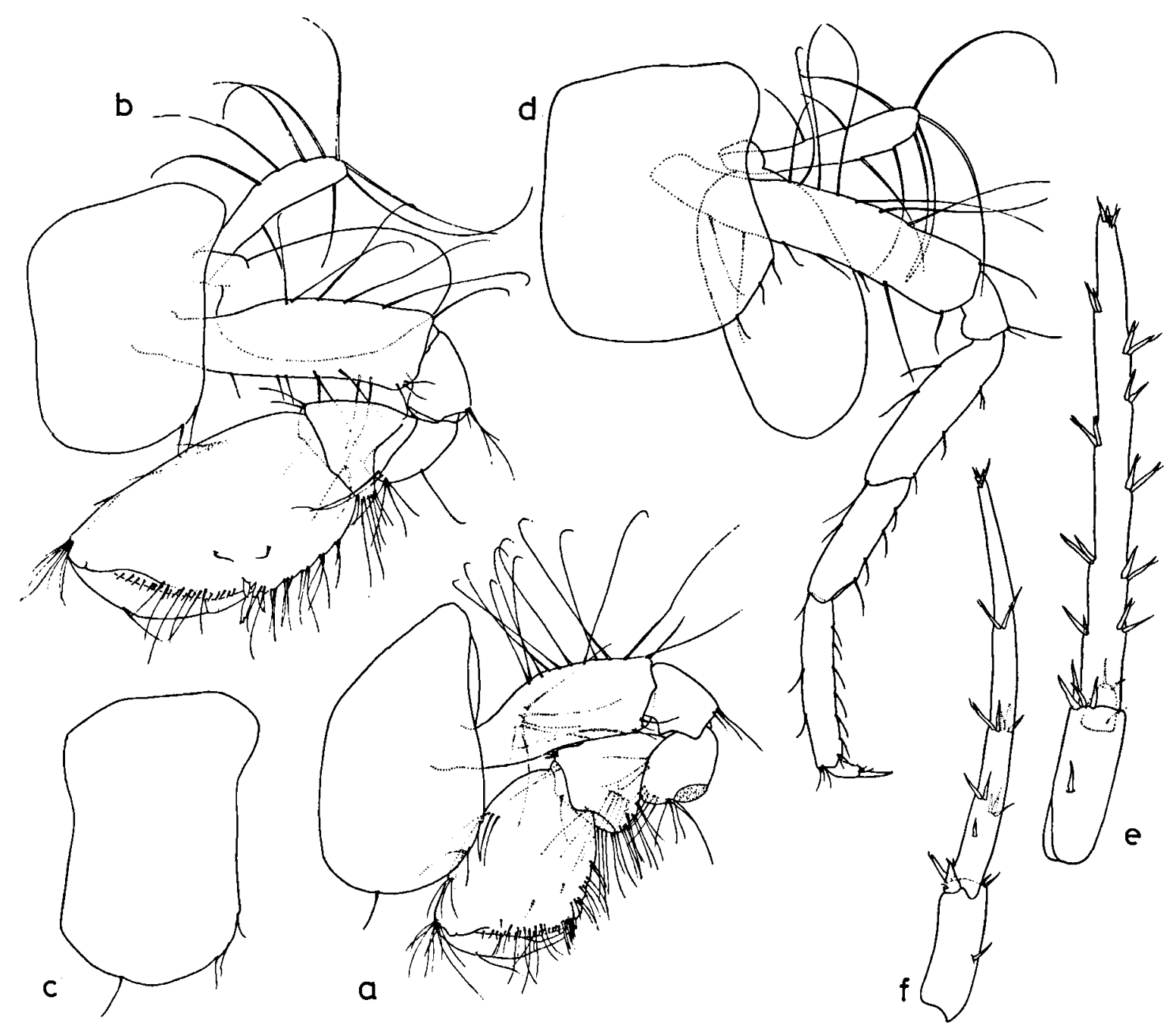

Fig. 3. Pseudoniphargus callaicus n. sp. (a-e, $\$$ paratype $6.0 \mathrm{~mm} ; \mathrm{f}$, o allotype): a, gnathopod 1 (scale D); b, gnathopod 2 (D); c, coxal plate 3 (D); d, pereiopod 4 (D); e, uropod 3 (D); f, uropod 3 (D).

ment 2. Flagellum 14- to 18-segmented, aesthetascs $2 / 3-3 / 4$ of length of corresponding segments, aesthetasc on penultimate segment exceeding length of last segment. Antenna 2 (fig. $2 \mathrm{~b}$ ): peduncle somewhat longer than that of antenna 1, segment 5 and flagellum with long setae. Flagellum 8- to 10-segmented, 1.01.5 times as long as peduncle segment 5 .

Mandible palp (fig. 2c): segment 2 with several ventral setae; segment 3 as long as segment 2, with $1 \mathrm{~A}$-seta, 2-3 B-setae, about $12 \mathrm{D}$ setae (not barbed), and 3-5 E-setae; proximal group of D-setae (C-setae ?) longer than other
D-setae. Maxilla 1 (fig. 2d): inner lobe with 3 subdistal setae and a terminal sensory setule; outer lobe with 7 slender spines, some of which with a few small denticles; palp slender and clearly longer than outer lobe. Maxilliped (fig. 2e): inner lobe rather short, outer lobe nearly as long as segments 1 and 2 of the palp.

Gnathopod 1 (fig. 3a): carpus short, with 4 rows of posterior setae; propodus with 3 groups of setae on posterior margin, palmar angle with 5 bicuspidate spines. Gnathopod 2 (fig. 3b): coxal plate about 1.5 times as long as wide; carpus short with a row of stiff posterodistal 


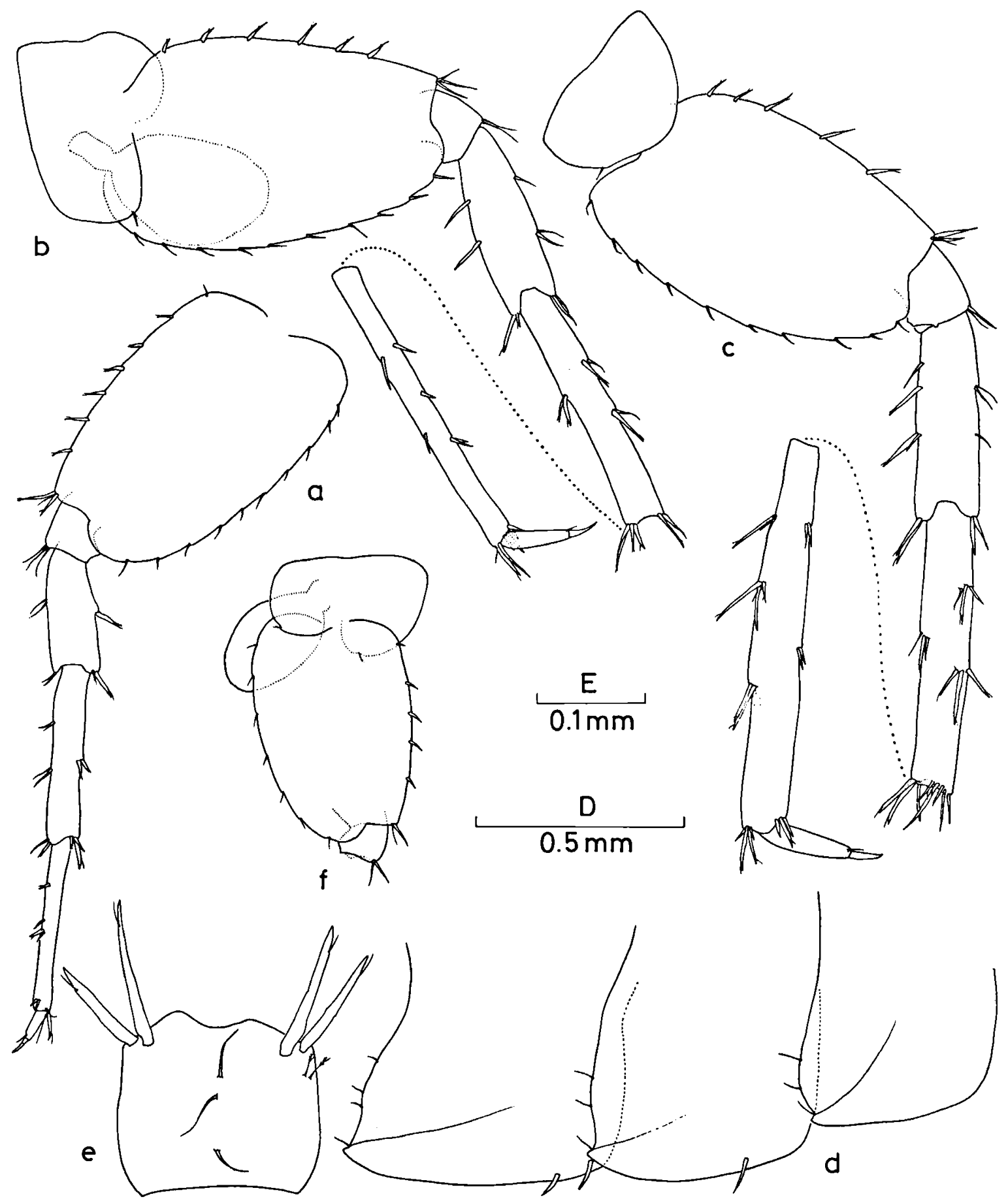

Fig. 4. Pseudoniphargus callaicus n. sp. (a-e, $\$$ paratype $6.0 \mathrm{~mm}$; $\mathrm{f}, \sigma^{\circ}$ allotype): a, pereiopod 5 (scale D); b, pereiopod 6 (D); c, pereiopod 7 (D); d, epimeral plates (D); e, telson (E); f, basis pereiopod 5 (D). 
setae; propodus with subparallel margins and 5 groups of posterior setae; palmar margin slightly convex, palmar angle with 3 rather short spines; unguis about $1 / 3$ of length of dactylus.

Pereiopods 3 and 4: coxal plate 3 (fig. 3c) 1.5-2.0 times as long as wide with $1+3$ ventral setae, plate 4 (fig. 3d) slightly longer than wide, with shallow posterior excavation and 3 posteroventral setae. Posterior margin of propodus (fig. 3d) with 5-6 elements, claw short with unguis as long as dactylus.

Pereiopods 5 to 7 (figs. 4a-c): length of pereiopod 5 subequal to pereiopod 4 , but much shorter than pereiopods 6 and 7 (P7 somewhat longer than $\mathrm{P} 6$ ). Basis with wide and overhanging posterior lobe, number of spinules on anterior margin 7 (P5), 6 (P6), or 5 (P7); posterior margin with 10 setules. Distal segments with low number of short spines; propodus of pereiopods 6 and 7 slender, with short posterodistal spines. Claw of pereiopod 5 short, that of pereiopods 6 and 7 somewhat longer; unguis about $1 / 2$ as long as dactylus.

Epimera (fig. 4d): ventral margin slightly convex, that of plate 1 unarmed, plates 2 and 3 with 1 and 2 slender anteroventral spines, respectively. Posteroventral corner with small tooth and a setule. Posterior margin of plates 1 and 2 slightly convex with 2 setules, that of plate 3 somewhat $\mathrm{S}$-shaped with 3 setules.

Uropod 1 (fig. 2f): peduncle slender with basoventral spine, a row of about 5 slender dorsal spines, no medial spines, 2 short distolateral spines, and distomedial spine lacking but a setule present. Rami slender without marginal armature, exopodite slightly shorter than endopodite. Uropod 2 (fig. 2g): peduncle slender with 1 medial and 1 distomedial spine; rami slender with unarmed margins. Uropod 3 (fig. 3e): peduncle 2.5-3.0 times as long as wide, with 1 marginal group of 1-2 spines and few distal spines. Endopodite with 1-2 apical spinules. Exopodite (fig. 3e shows dorsal view) tapering and slightly curved, 11-12 times as long as its basal width, margins with 4-5 spine groups, each group with 2 or sometimes 3 spines, terminal spines very short.
Telson (fig. 4e) subquadrate with 2 subterminal spines on either side, lateral spine shorter than medial one, distal notch wide and shallow.

Male: The only male available for study is probably subadult. The maxilla 1 has only 2 setae on its inner lobe. No important differences with the female are found. The basis of pereiopod 5 (fig. 4f) and uropod 3 in lateral view (fig. $3 f$ ) are illustrated.

Remarks. - This species deviates from all other species of the genus by absence of the distomedial spine on the peduncle of uropod 1 . The mandible palp with a proximal group of longer D-setae is a character shared only by the two Bermudian species Ps. grandimanus and carpalis, both described by Stock et al. (1986). However, in these two this setal group consists of only two setae (named C-setae by Stock et al., 1986).

In many features Ps. callaicus resembles mateusorum Stock, 1980 from central Portugal. Both belong to species of Pseudoniphargus in which the basis of pereiopods 5 to 7 is somewhat extended and the male uropod 3 is not strongly elongate and more or less similar to that of the female. Moreover, through the slender marginally unarmed rami of uropods 1 and 2, the slender, tapering and slightly curved exopodite of uropod 3, and the shape and armature of the telson, callaicus seems to be closely related to mateusorum.

Besides the unique feature of $P$ s. callaicus, viz. the absence of the distomedial peduncle spine on uropod 1, this species is differentiated from mateusorum by its short carpus of gnathopod 1 , a more elongate peduncle of uropod 3 which is provided with marginal armature, and an oblique, S-shaped posterior margin of epimeral plate 3 .

Etymology. - The new species Ps. callaicus is named after the region Galicia, in which it was found. This region was named Galaecia, Gallecia, or more commonly Callaecia by the Romans and in that time part of Hispania Tarraconensis. 
TAXONOMIC REMARKS ON PORTUGUESE SPECIES

\author{
Pseudoniphargus mateusorum Stock, 1980 \\ (Figs. 5-6)
}

Stock, 1980: 133, fig. 20.

Material examined. - Portugal, Costa da Arrábida (Bay of Setubal), Lapa dos Morcegos (bat cave); 26 June 1941, $1 \sigma^{\circ}$ holotype, $1 \sigma^{\circ}$ and $46 \%$ (paratypes), leg. A. Barros Machado (Zoologisches Museum der Humboldt Universität, Berlin, coll. no. 25248).

Descriptive notes. - Largest female 6.8 $\mathrm{mm}$, not ovigerous but possessing setose oostegites, no ovigerous females in the material studied. Contradictorily, Stock mentioned the presence of a $4.5 \mathrm{~mm}$ long ovigerous female with 5 eggs. Within the series of 46 female and juvenile paratypes another male was found of about the same size as the holotype, $4.5 \mathrm{~mm}$.

Female: Antenna 1 somewhat shorter than half the body length. Antenna 2 (fig. 5a): peduncle slightly longer than that of antenna 1 , segment 4 with some rather long distal spines; flagellum 6-segmented, about 1.5 times as long as last peduncle segment.

Mandible palp segment 2 with several ventral setae, segment 3 about as long as segment 2 with $1 \mathrm{~A}$-seta, $1 \mathrm{~B}$-seta, 12 slender D-setae, and 3 E-setae. Outer lobe of maxilla 1 with the 2 lateral spines multidenticulate, remaining 5 spines smooth. Maxillipedal palp and its claw slender.

Gnathopod 1: carpus slightly shorter than propodus. Gnathopod 2: coxal plate more or less similar to plate 1 , almost 1.5 times as long as wide; carpus short with 2 posterior setal groups; propodus (fig. 5b) rather slender, subrectangular, palma slightly convex and not strongly oblique, palmar angle with 3 spines (1 longer).

Pereiopods 3 and 4 (fig. $6 \mathrm{~d}$ ): coxal plate 3 (fig. 6c) 1.5-2.0 times longer than wide; plate 4 slightly wider than plate 3 and hardly excavate posteriorly; claws short, unguis as long as dactylus. Oostegites rather slender with 6-8 setae (fig. 6d).

Pereiopods 5 to 7 (figs. $5 c, d$; $6 \mathrm{e}$ ): basis with rather straight anterior margin bearing 6-7 spinules, posterior lobe developed with slightly overhanging distal corner, posterior margin slightly crenulate (fig. 5e) with 9-10 setules. Propodus of pereiopods 6 and 7 (fig. 5d) slender with short posterodistal spines, claw slender, unguis about half as long as dactylus in pereiopods 6 and 7, and about 2/3 of length of dactylus in pereiopod 5 .

Epimera (fig. 5f): ventral margin of plate 1 unarmed, that of plates 2 and 3 both with 2 slender anteroventral spines, posteroventral corner rounded; posterior margin with some long setules.

Uropod 1 (fig. 5g): peduncle slender with small basoventral spine, 2 dorsal spines and no medial spines, distomedial spine up to $1 / 4$ of length of endopodite; rami slender without marginal armature, terminal spines rather short, exopodite somewhat shorter than endopodite. Uropod 2 (fig. $5 \mathrm{~h}$ ): peduncle with 1 dorsal spine and 2 distal spines on either side, rami slender without marginal armature, terminal spines short. Uropod 3 (fig. $5 \mathrm{i}$ ): peduncle twice as long as wide, without marginal armature; exopodite about 12 times as long as wide, tapering, with short marginal spines and few terminal spines.

Telson: distal emargination shallow and wide; 2 spines on either side (lateral one clearly shorter than medial one), somewhat subapically implanted.

Male: Smaller than female. Sexual differences in uropod 3 less convincing than those described and illustrated by Stock $(1980$, cf. his figs. $20 \mathrm{k}$ and $\mathrm{l}$ with fig. $5 \mathrm{i}$ in the present paper). Mandible palp (fig. 6a) and distal part of gnathopod 1 (fig. 6b) illustrated.

Remarks. - This species strongly resembles Ps. brevipedunculatus Stock, 1980 and Ps. callaicus n. sp. by the somewhat expanded basis of the posterior three pairs of pereiopods, the tapering and slender exopodite of uropod 3 in both sexes, the unarmed margins of the rami of uropods 1 and 2, and the telson with 2 terminal spines only on either side. 


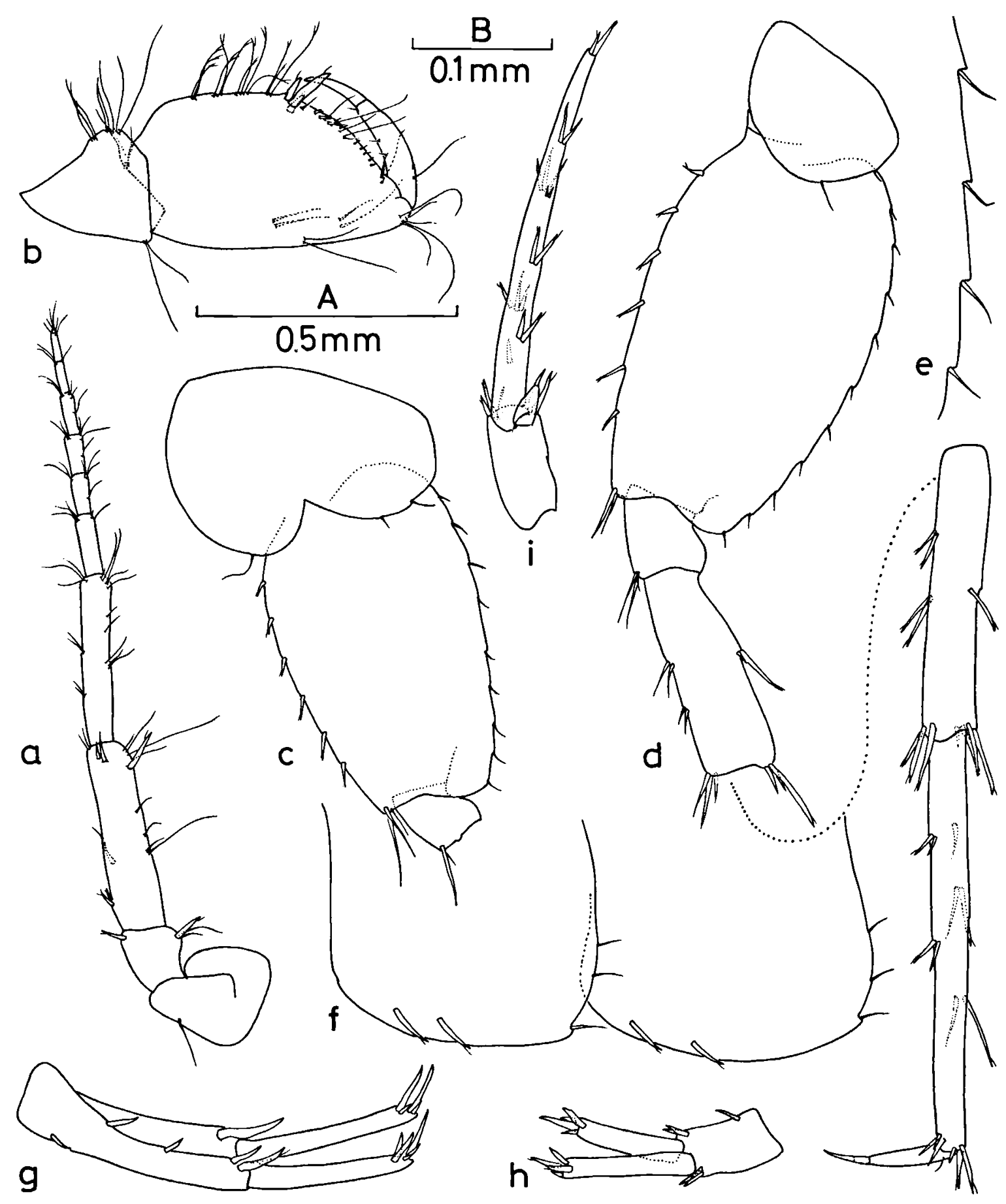

Fig. 5. Pseudoniphargus mateusorum Stock, 1980, $\odot$ paratype $6.8 \mathrm{~mm}$ : a, antenna 2 (scale A); b, distal part gnathopod 2 (A); c, basis pereiopod 5 (A); d, pereiopod 7 (A); e, distal part posterior margin basis pereiopod 7 (B); f, epimeral plates 2 and 3 (A); g, uropod 1 (A); h, uropod 2 (A); i, uropod $3(A)$. 


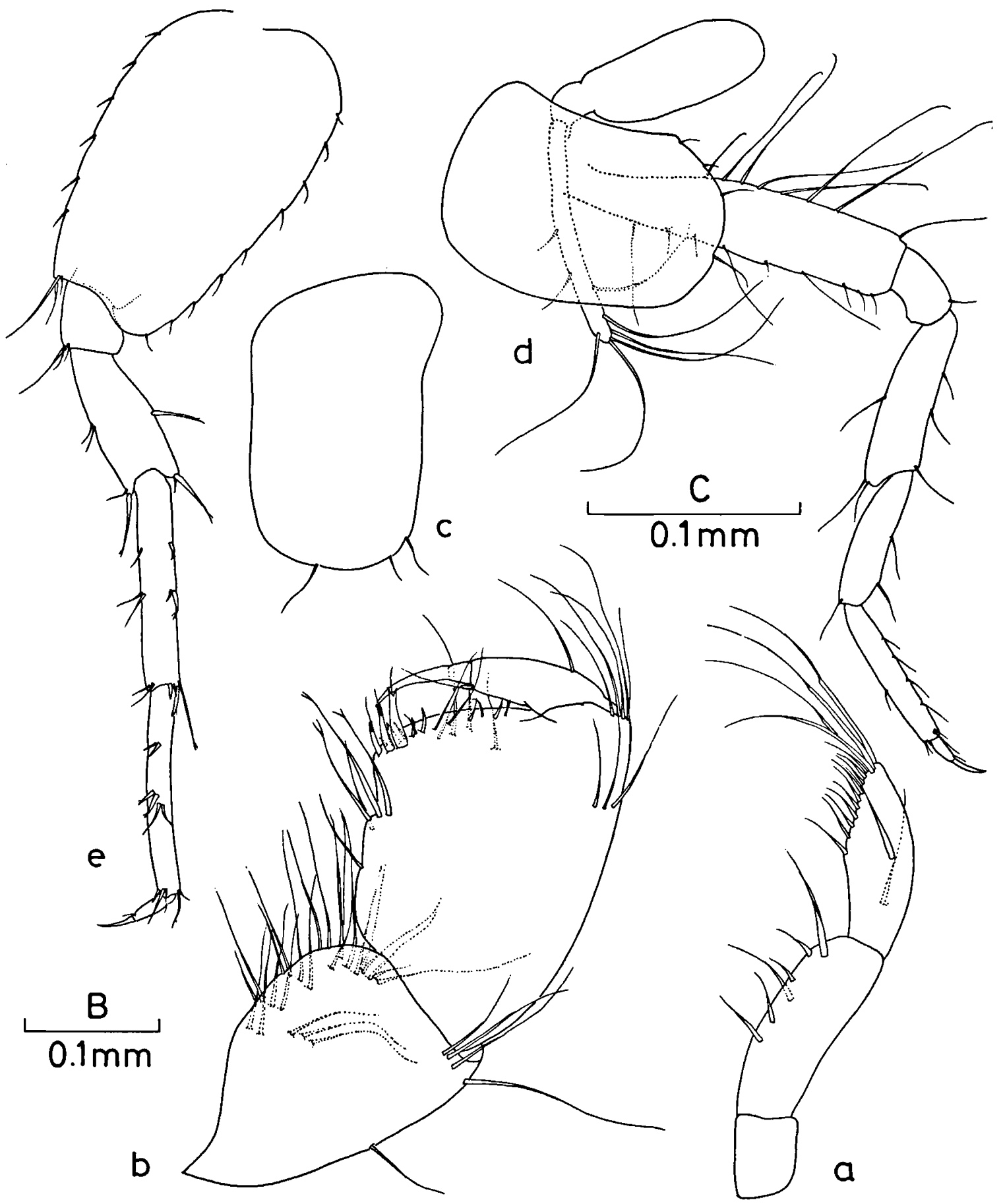

Fig. 6. Pseudoniphargus mateusorum Stock, 1980 (a-b, ơ holotype $4.5 \mathrm{~mm}$; c-e, $९$ paratype $6.8 \mathrm{~mm}$ ): a, mandible palp (scale C); b, distal part gnathopod 1 (B); c, coxal plate pereiopod 3 (A); d, pereiopod 4 (A); e, pereiopod 5 (A). 


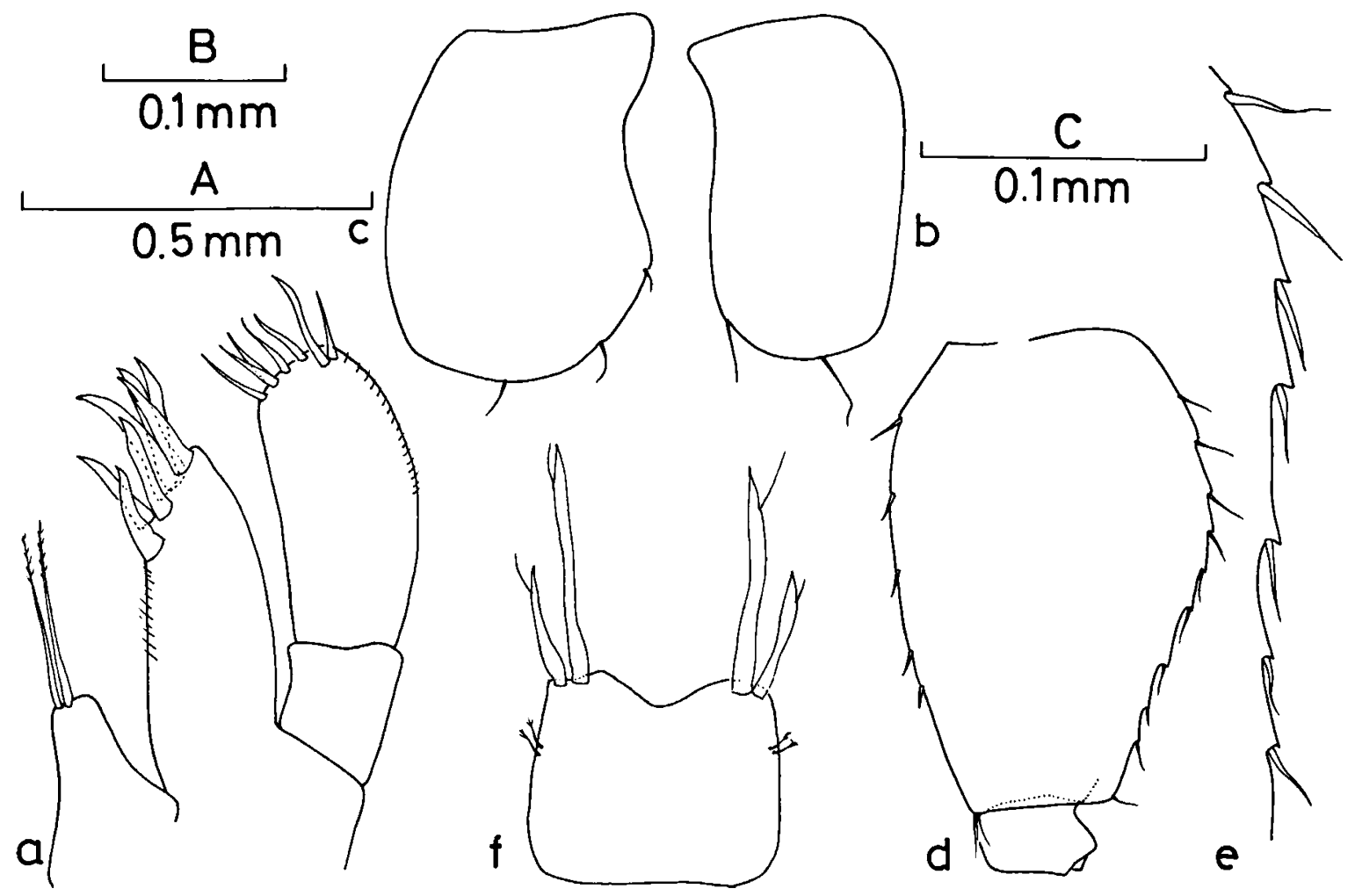

Fig. 7. Pseudoniphargus longispinum Stock, 1980, o holotype: a, maxilla 1 (scale C): b, coxal plate pereiopod 3 (A); c, coxal plate pereiopod 4 (A); d, basis pereiopod 7 (A); e, distal part posterior margin basis pereiopod 7 (B); f, telson (B).

Stock (1980) already pointed out the strong resemblance of this species to Ps. brevipedunculatus from the Azores; both have very similar gnathopods, pereiopods, uropods, and telson. However, in brevipedunculatus the exopodite of uropod 1 bears sometimes a weak marginal spine and the telson has a deeper distal notch. Furthermore, mateusorum has a more slender claw on the posterior pereiopods and a rounded posteroventral corner of the epimera. The affinities of mateusorum with callaicus are discussed under the latter species.

Pseudoniphargus longispinum Stock, 1980 (Fig. 7)

Stock 1980: 130-133, figs. 18-19.

Material examined. - Portugal, prov. Beira Litoral, well near Ponte de Mucela (E. of Coimbra); 14 June 1958, 1 \& holotype microscopical slides only (Instituto de Zoologia "Dr. Augusto Nobre", Universidade do Porto).
Descriptive notes. - Female holotype: Antenna 2 with few small spines on peduncle segment 4; flagellum 8-segmented, about 1.5 times as long as last peduncle segment.

Mandible palp as in mateusorum. Maxilla 1 (fig. 7a): outer lobe with 7 slender smooth or unidenticulate spines, palp segment 2 rather wide.

Gnathopod 2: coxal plate slightly more than 1.5 times as long as wide with 2 rather long ventral setae; carpus short; propodus stronger than in mateusorum with oblique and S-shaped palmar margin.

Pereiopods 3 and 4: coxal plate 3 (fig. 7b) about twice as long as wide, plate 4 (fig. 7c) with distinct posterior excavation. Propodus posteriorly with 4 setae; claw slender, unguis slightly longer than dactylus.

Pereiopods 5 to 7: basis (fig. 7d) tapering, with convex margins, posterior lobe weak and 
not overhanging; setules on posterior margin of basis of pereiopods 6 and 7 implanted in clear notches (fig. 7e); distal segments with few, short spines; claw slender, with unguis as long as dactylus in pereiopod 5 , and shorter than dactylus in pereiopods 6 and 7.

Uropod 1: medial spines on peduncle lacking; distomedial spine reaching almost up to half the length of exopodite; rami rather short without marginal armature, exopodite slightly shorter than endopodite. Terminal spines of rami long; however, their great length is relative, due to the rather short length of the rami. Uropod 2: peduncle with 1 dorsal spine and 1 distal spine on either side; rami without marginal armature. Uropod 3: peduncle 1.5 times as long as wide; exopodite not tapering, 6.5 times as long as wide, with 2 groups of spines on either side, each of 2 spines, terminal spines slightly longer than marginal spines.

Telson (fig. 7f) as in Ps. mateusorum.

Remarks. - The type-material placed at our disposition by the Instituto de Zoologia "Dr. Augusto Nobre" comprised alcohol material and two microscopical slides of the female holotype. The specimens stored in alcohol were in two tubes. The first tube, of which the label mentioned 1 female holotype and 1 female paratype from the locality Anadia, contained a single specimen still possessing both its uropods and therefore not the dissected holotype. The text on the label of this tube is contradictory to what was stated by Stock (1980: 130). This author mentioned 1 female holotype and 1 male paratype from a well at Ponte de Mucela. The label of the second tube mentioned 3 fragmentary males from Anadia, whereas the contents were 18 dried specimens, identified by the present author as Ps. cf. brevipedunculatus Stock, 1980. Consequently the morphological remarks in this paper are based only on the examination of the microscopical slides of the female holotype.

Little material of this species is available. From the female holotype, which is probably lost, only the slides made from the dissected body parts could be traced, and only one paratype has been designated. So, for a better understanding of sexual dimorphism and morphological variation within this species a redescription is necessary, based on a good series of males and females from the typelocality. Until then the taxonomic position of this species cannot be ascertained.

Stock (1980) mentioned as an important difference between this species and Ps. mateusorum elongation of the exopodite of male uropod 3. This character appears to be less convincing than the shape of the propodus of pereiopod 2 , shape of the basis of pereiopods 5 to 7 , and armature of the uropods. The length of the terminal spines on the rami of uropods 1 and 2 are not as aberrant as described by Stock (1980) but have a rather long appearance due to the rather short length of the rami.

\section{Pseudoniphargus brevipedunculatus Stock, 1980}

Stock, 1980: 133-137, figs. 21-22.

Material examined. - Azores, Faial, Horta, well no. 2 along the coast; 2/3 Apr. 1957, 1 \% holotype, 1 \% allotype, and 56 paratypes, Exped. P. Brinck \& E. Dahl, loc. 83 (Zoologiska Institutionen, Avdelningen for Systematik, Lund, cat. no. 1).

Descriptive notes. - Mandible palp segment 3 with 9-12 D-setae, 2 A-setae, 1 B-seta, and 3 E-setae. Outer lobe of maxilla 1 with 4 medial spines bearing several small denticles, and 3 lateral spines with only 1 rather strong denticle; palp not exceeding length of spines on outer lobe.

Gnathopod 1: carpus slightly shorter than propodus with 4 rows of posterior setae; propodus with 2 setal rows on posterior margin; palmar angle with 6 bicuspidate spines. Gnathopod 2: coxal plate subsimilar to plate 1, about 1.5 times as long as wide, ventral margin with $1+3$ setae; carpus short with 3 groups of stiff setae on posterior lobe; shape and armature of propodus as described by Stock; palmar margin slightly convex, palmar angle with 3 spines (one longer and one smaller implanted 
more inside). No differences observed in gnathopodal morphology between both sexes.

Pereiopods 3 and 4: coxal plate 3 about 1.5 times as long as wide, ventral margin with $1+2$ setae; plate 4 hardly excavate posteriorly, ventral margin with $1+5$ setae; posterior margin of propodus with 6 spinules; claw rather short with unguis as long as dactylus.

Pereiopods 5 to 7: anterior margin of basis rather straight, posterior margin convex with many setules. Posterodistal corner somewhat overhanging, in males this corner is more rounded than in females, smaller specimens apparently have a more overhanging corner. Inner subdistal spinules of basis (see Stock: fig. 22f) sometimes present. Distal spines on propodus not exceeding the length of the dactylus.

Epimera: ventral margin of plate 1 rather straight with 1 spine; plates 2 and 3 with slightly more convex ventral margin bearing 2-3, and 3-4 spines, respectively. Posteroventral corner with small, blunt tooth; posterior margin slightly convex with 2 setules on plates 2 and 3 .

Uropod 1: peduncle with weak basoventral spine, 3 dorsal spines, medial spines lacking, and distomedial spine shorter than half the length of the endopodite; rami slender, exopodite slightly curved and somewhat shorter than endopodite, distal spines short, exopodite sometimes with a small marginal spine: Uropod 2: peduncle with 2 lateral and $1+2$ distal spines; rami rather slender with short distal spines, exopodite sometimes with small marginal spine. Uropod 3: peduncle about twice as long as wide; exopodite tapering with short distal spines, margins with many groups of rather long spines. Male exopodite 8-14 times as long as wide, female exopodite 6.5-9.5 times as long as wide.

Telson as described by Stock (1980).

Remarks. - The strong resemblance of this species to Ps. mateusorum from central Portugal is already noted under the latter species. Differences and similarities between brevipedunculatus and callaicus from Galicia are comparable to those between the latter and mateusorum.

\section{DISCUSSION}

Within the genus Pseudoniphargus a weakly defined Lusitanian-Azorian group of species, composed of brevipedunculatus, mateusorum, and callaicus, can be recognized. The most important feature by which this group can be distinguished is the combination of: rami of uropods 1 and 2 without marginal spines (exceptionally only the exopodite bears a small marginal spine); exopodite of uropod 3 tapering, slender, slightly curved and not or very weakly sexually differentiated; and telson with only 2 spines (lateral one shorter) on either side.

Furthermore, the members of this species group have rather deep coxal plates, plate 4 hardly excavate posteriorly, the basis of pereiopods 5 to 7 somewhat expanded with overhanging posterodistal corner, and medial spines on the peduncle of uropod 1 lacking. The last set of characters is found in several north Spanish species of Burgos and Basque country as well (e.g. Ps. jereanus, gorbeanus, guernicae). However, most of these north Spanish species exhibit sexual dimorphism in gnathopod 2 and have an elongate claw of pereiopod 4.

The second species from Portugal, Ps. longispinum, seems to agree in many characters with the other species of the area but deviates in the strong propodus of gnathopod 2, the shape of the basis of pereiopods 5 to 7, less slender rami of uropods 1 and 2, and the shape of the exopodite of uropod 3 . This species, however, will not be included further in our discussion because of insufficient taxonomic knowledge.

Comparing the species of the LusitanianAzorian group with their south Spanish congeners, only Ps. gibraltaricus agrees by: shape of basis of posterior pereiopods, unarmed margins of rami of uropods 1 and 2, and shape and armature of exopodite of uropod 3. Ps. gibraltaricus shares with callaicus the presence of a marginal spine on the peduncle of uropod 3. The remaining south Spanish species undoubtedly differ from the LusitanianAzorian group in one or more of the following characters: presence of a narrow basis in the 
posterior pereiopods, medium-deep coxal plates, spinose uropods and telson, a strong propodus of the gnathopods, or a strongly elongate exopodite of uropod 3 in males.

The two species, Ps. grandimanus and carpalis, recently described from Bermuda (Stock et al., 1986) are in several features reminiscent of the Lusitanian-Azorian group. This is above all clear when Ps. grandimanus is compared with callaicus. Both species share: mandible palp with a group of longer proximal D-setae, inner lobe of maxilla 1 sometimes with 3-4 setae, coxal plates rather deep, basis of pereiopods 5 to 7 somewhat expanded and posterodistally overhanging, rami of uropods 1 and 2 slender and without marginal armature, exopodite of uropod 3 tapering and with short terminal spines. On the other hand, grandimanus has a sexually dimorphic gnathopod 2, many spines on the ventral margin of the epimera, many setules on the ventral margins of coxal plates 3 and 4 , and a telson with up to 3 spines on either side by which it differs from callaicus and the other members of the Lusitanian-Azorian group.

The only characters by which the Bermudian species differ from all their east Atlantic congeners are the presence of up to 5 spines on the ventral margin of epimeral plates 2 and 3 , and the setose ventral margins of coxal plates 3 and 4. Stock et al. (1986) mention the following characters as unique as well: the presence of a hyaline posterior lobe on the merus of gnathopod 1, slender rami of uropods 1 and 2, and an unarmed tip of the telson lobes. However, the hyaline lobe of gnathopod 1 is found in all species of the genus (see diagnosis in Notenboom, 1986), while slender rami of uropods 1 and 2, and unarmed tips of the telson are found in Ps. brevipedunculatus and several Iberian representatives of the genus.

Summarizing the taxonomic position of the new species, Ps. callaicus (described in this paper), it belongs to a weakly defined cluster of species, including mateusorum and brevipedunculatus. This group is distributed in Lusitania and the Azores and therefore named herein the Lusitanian-
Azorian group. The affinities of this group, based on phenetic resemblance, seem to be closer to the Bermudian and north Spanish species, and to gibraltaricus from southern Spain, than to the remaining species of the genus.

\section{CHECKLIST AND KEY OF IBERIAN PSEUDONIPHARGUS SPECIES}

At present, 31 species are recognized from continental groundwaters of the Iberian Peninsula (Stock, 1980; Notenboom, 1986, 1987, and present paper). These species with their biotope and area of distribution are listed here.

affinis Notenboom, 1987: 107 (springs; Sierra Gorda, northwestern Granada)

branchiatus Stock, 1980: 140 (wells and hyporheic waters; northeastern Betics, Valencia and Alicante)

burgensis Notenboom, 1986: 97 (cave waters; Ojo Guareña cave system, northern Burgos)

callaicus n. sp. (well; along coast of northwestern Galicia) cazorlae Notenboom, 1987: 123 (hyporheic waters; Guadalquivir basin, Sierra de Cazorla, Jaén)

eborarius Notenboom, 1986: 100 (springs; northern Burgos)

elongatus Stock, 1980: 137 (wells, springs, hyporheic and cave waters; Cantabria mainly and northern Burgos)

fragilis Notenboom, 1987: 139 (wells and hyporheic waters; east side of Serranía de Ronda, Málaga, and probably Sierra Gorda, northwestern Granada)

gibraltaricus Notenboom, 1987: 143 (wells and hyporheic waters; southeastern Cádiz)

gorbeanus Notenboom, 1986: 105 (cave waters; Sierra de Gorbea, northern Alava)

gracilis Notenboom, 1987: 130 (wells; valley of the Río Almanzora, Almería)

granadensis Notenboom, 1987: 100 (hyporheic waters; northeastern slopes of Sierra Nevada, around Granada)

grandis Notenboom, 1987: 103 (wells, springs, hyporheic and cave waters; northeastern Málaga, and probably central Granada)

guernicae Notenboom, 1986: 116 (cave waters and springs; around Ria de Mundaca, coastal area north of Guernica, Vizcaya)

illustris Notenboom, 1987: 117 (hyporheic waters; Guadalquivir basin, southern Jaén)

incantatus Notenboom, 1986: 112 (cave waters; southern slopes of western extensions of Pyrenees, Navarra and Guipuzcoa)

jereanus Notenboom, 1986: 103 (cave waters; northeastern Burgos)

latipes Notenboom, 1987: 126 (hyporheic waters; Guadalquivir basin, Jaén and Sevilla) 
longicarpus Notenboom, 1986: 85 (hyporheic waters and springs; north side Cantabrian Mountains in eastern Asturias)

longispinum Stock, 1980: 130 (wells; Portugal, around Coimbra, Beira Litoral)

margalefi Notenboom, 1987: 120 (resurgence; northeastern Alicante)

mateusorum Stock, 1980: 133 (cave waters; Portugal, Sierra de la Arrábida near Setubal)

montanus Notenboom, 1986: 91 (hyporheic waters; south side Cantabrian Mountains in León and upper course Río Sella north of this mountain ridge in eastern Asturias)

nevadensis Notenboom, 1987: 97 (hyporheic waters; southern slopes Sierra Nevada, Granada and Almería)

semielongatus Notenboom, 1986: 87 (springs, hyporheic and cave waters; north side Cantabrian Mountains in eastern Asturias and western Cantabria)

sorbasiensis Notenboom, 1987: 134 (wells and cave waters; around Sorbas, central Almería)

spiniferus Notenboom, 1986: 119 (hyporheic waters; northeastern Navarra)

stocki Notenboom, 1987: 111 (wells and cave waters; Serranía de Ronda, eastern Cádiz and northwestern Málaga)

unisexualis Stock, 1980: 127 (cave waters; Sierra de Urkilla, Guipuzcoa)

vasconiensis Notenboom, 1986: 108 (cave waters and springs; southwestern Guipuzcoa, western Navarra, and northeastern Alava)

vomeratus Notenboom, 1987: 112 (springs; northern slopes of Sierra de Segura, eastern Jaén)

The Iberian species of Pseudoniphargus can be identified with the following key. Morphological differences between several species are small. The majority of species cannot be diagnosed by a single, unique morphological structure; usually they show other combinations of characters which occur separately in other species. Some species are characterized by the expression of secondary sexual differences in some of the appendages. Subadult specimens may differ from adults in the morphology of particularly gnathopods, pereiopods and uropods. Hence, it is advisable that one needs a good series of adult males and females when identifying Pseudoniphargus.

Further study of Iberian groundwaters may yield extensions of the presently known distributions of many species and may elucidate the taxonomic position of a number of problematic forms. Considering the cryptic nature of the groundwater fauna, and the very localized and disjunct distribution of many species, further discovery of new taxa is to be expected.

1. Exopodite of male U3 strongly elongated (more than 15 times as long as wide) and upcurved. Female U3 not as strongly elongated as that of male (up to 15 times as long as wide)

- Exopodite of male U3 not strongly elongated (up to 14 times as long as wide), straight and more or less similar to that of female ....................... 10

2. Posterior lobe of basis of P5-P7 wide and overhanging. Exopodite of fernale U3 with short spines (not exceeding the width of exopodite)

elongatus Stock, 1980

- Posterior lobe of basis P5-P7 narrow and not overhanging. Exopodite of female U3 with long spines

3. Posteroventral corner of epimera strongly produced. Telson of male longer than wide, tapering and with straight lateral margins ......................... 4

- Posteroventral corner of epimera not strongly produced, rounded or sometimes with a small tooth. Telson of male wider than long or subquadrate 5

4. Telson of male 1.5 times as long as wide, that of female wider than long; distal emargination of telson $\mathrm{V}$-shaped. Spines of outer lobe of $\mathrm{Mx} 1$ not combed, bearing small denticles only. Peduncle of U1 with dorsal row of up to 8 spines. Propodus of $\mathrm{Gn} 2$ male robust .................. vomeratus Notenboom, 1987

- Telson of male and female slightly longer than wide, distal notch lacking or wide and shallow. Outer lobe of $\mathrm{Mx} 1$ with 5 combed spines. Peduncle of U1 with up to 3 dorsal spines. Propodus of Gn2 male not very strong .................... illustris Notenboom, 1987

5. Peduncle of U3 male up to 4 times as long as wide, marginal spines usually lacking ................ 6

- Peduncle of U3 male more than 4 times as long as wide, with several marginal spines ............. 7

6. Posteroventral corner of epimera rounded. Outer lobe of $\mathrm{Mx1}$ with one or more multidenticulate spines. Telson with up to 8 spines on either side

cf. branchiatus Stock, 1980

- Posteroventral corner of epimera pointed. Outer lobe of $\mathrm{Mx1}$ with unidenticulate spines only. Telson with up to 3 spines on either side (medial spines the longest) ............... nevadensis Notenboom, 1987

7. Telson with convex lateral margins and two separate groups of spines on either side. Peduncle of $U 1$ with up to 6 dorsal and 3 medial spines

granadensis Notenboom, 1987

- Telson with straight lateral margins and with 1 group of spines on either side. Peduncle of U1 with up to 4 dorsal spines and 0-3 medial spines ............ 8

8. Outer lobe of $\mathrm{Mx1}$ with 8 spines. A2 with long setae. Propodus of $\mathrm{Gn} 2$ male rather slender with slightly oblique palmar margin. Exopodite of U3 male 20 times as long as wide ..... stocki Notenboom, 1987 
- Outer lobe of Mx1 with 7 spines. A2 with short setae. Propodus of male $\mathrm{Gn} 2$ wide with oblique, S-shaped palmar margin. Exopodite of U3 male more than 20 times as long as wide

9. Epimera with rectangular posteroventral corner. Telson with wide distal notch and 3-4 subterminal spines on either side ..... affinis Notenboom, 1987

- Epimera with rounded posteroventral corner. Telson distally with narrow notch and flattened lobes each bearing a row of $6-8$ spines

grandis Notenboom, 1987

10. Basis of P7 male slender, with straight margins, more or less subrectangular, posterior lobe always narrow and not overhanging

- Basis of P7 male with convex margins, more or less ovoid in shape, posterior lobe mostly well developed and sometimes strongly overhanging....

15

11. Propodus of $\mathrm{Gn} 1$ male strong and distally widened latipes Notenboom, 1987

- Propodus of male Gn1 "normal", subrectangular ......................................... 12

12. Epimera with rounded posteroventral corner. Gn1 and 2, and coxae 3 and 4 sexually dimorphic. Telson wider than long, with $\mathrm{V}$-shaped distal notch, terminal lobes flattened with 5 long spines (in subadult males and females basis of P5-P7 with convex margins and weak posterior lobe) ..... fragilis Notenboom, 1987

- Posteroventral corner of epimera rectangular with minute tooth. Gnathopods and coxae 3 and 4 not sexually dimorphic. Distal margin of telson straight or with shallow excavation $\ldots . . . \ldots \ldots \ldots \ldots \ldots \ldots \ldots, 13$

13. Ventral margin of epimera spinous. Exopodite of U3 with long spines, terminal spines longer than marginal spines. Flagellum of A2 shorter than peduncle segment 5. Rami of U1 slender with several spines ..................... sorbasiensis Notenboom, 1987

- Ventral margin of epimera hardly spinous. Flagellum of A2 slightly longer than peduncle segment 5. Rami of $U 1$ not very slender, almost without armature 14

14. Telson longer than wide with broad V-shaped distal excavation. Peduncle of U1 with medial spines. Dorsal surface of peduncle and rami of U2 with many spines .................... spiniferus Notenboom, 1986

- Telson subquadrate with very slight terminal excavation. Peduncle of U1 without medial spines. U2 poorly spinous .............. unisexualis Stock, 1980

15. Mandible palp segment 3 with about 5 D-setae. Claw of P7 very slender with unguis 1/4-1/5 of length of dactylus. Gn1 and 2 very slender with elongated carpus and poorly developed armature on palmar margin. Exopodite of U3 with long spines ........... gracilis Notenboom, 1987

- Mandible palp segment with about 10 or more Dsetae. Unguis of claw of P7 not very short .... 16

16. Posterior lobe of basis of P5-P7 weakly developed, not markedly overhanging. Claw of $\mathrm{P} 4$ not very slender. Carpus of $\mathrm{Gn} 2$ male short

- Posterior lobe of basis of P5-P7 well developed and slightly or strongly overhanging. Claw of P4 often very slender. Carpus of $\mathrm{Gn} 2$ of male sometimes elongated

17. U1 without medial peduncle spines, rami without marginal spines .............................. 18

- U1 with 1-3 medial peduncle spines, one or both rami with marginal spines

19

18. Outer lobe of $\mathrm{Mx} 1$ with smooth or unidenticulate spines. Propodus of $\mathrm{Gn} 2$ rather wide with S-shaped palmar margin. Basis of P6 and P7 tapering, posterior margin slightly serrate .... longispinum Stock, 1980

- Outer lobe of Mx1 with multidenticulate spines. Propodus of $\mathrm{Gn} 2$ rather slender with convex palmar margin. Basis of P6 and P7 ovoid, posterior margin not serrate ......... gibraltaricus Notenboom, 1987

19. Telson trapezoid, short, and distally hardly emarginate. Peduncle of U3 without marginal spines

......................... margalefi Notenboom, 1987

- Telson with rather deep distal notch. Peduncle of U3 with 1 marginal spine .. cazorlae Notenboom, 1987

20. Telson with 2 spines on either side. Rami of U1-U2 slender without marginal armature. Exopodite of U3 elongate and tapering. Carpus of $\mathrm{Gn} 2$ similar in both sexes

- Telson with more than 2 spines on either side. One or both rami of U1-U2 with marginal spines. Exopodite of U3 linear or slightly tapering. Carpus of Gn2 female usually longer than in male ............ 22

21. Peduncle U1 with a distomedial setule. Peduncle U3 2.5-3.0 times as long as wide with marginal spine. Mandible palp with proximal group of longer D-setae callaicus $\mathrm{n}$. sp.

- Peduncle U1 with strong distomedial spine. Peduncle U3 twice as long as wide without marginal spine. Mandible palp without proximal group of longer Dsetae ...................... mateusorum Stock, 1980

22. $\mathrm{U} 1$ with medial peduncle spines. Both rami of $U 1$ and U2 with marginal armature. Ventral spines on epimera present. Claw of P3 and P4 not slender 23

- U1 without medial peduncle spines. Only endopodite of $\mathrm{U} 1$ and $\mathrm{U} 2$ sometimes with a few marginal spines. Ventral spines on epimera usually absent. Claw of P3 and $\mathrm{P} 4$ slender

23. Carpus of $\mathrm{Gn} 2$ strongly elongated; propodus slender, as wide as carpus. Coxa 3 short and narrow. Coxa 4 wide, longer than coxa 3. Palp of $\mathrm{Mx1}$ wide ........ longicarpus Notenboom, 1986

- Carpus of Gn2 not elongated, propodus wider than carpus. Coxa 3 as long as coxa 4. Palp of Mx1 not wide ......................................... 24

24. Exopodite of U3 male 8-10 times as long as wide. Telson with distinctly V-shaped distal notch. Basis of P6 as long as that of P7

semielongatus Notenboom, 1986

- Exopodite of U3 male 6-7 times as long as wide. Telson distally hardly excavate. Basis of P6 longer than that of P7 ........ montanus Notenboom, 1986

25. Carpus of $\mathrm{Gn} 2$ male elongate. Outer lobe of $\mathrm{Mx} 1$ with 
6 spines, inner lobe with 1 seta

burgensis Notenboom, 1986

- Carpus of Gn2 male not elongate. Outer lobe of Mx1 with 7 spines, inner lobe with 2 setae .......... 26

26. Propodus of $\mathrm{Gn} 2$ male with strongly oblique palma and short claw; palmar angle spines robust. Telson wider than long, with wide $\mathrm{V}$-shaped distal excavation .................... incantatus Notenboom, 1986

- Propodus of $\mathrm{Gn} 2$ male subrectangular, palmar margin not very oblique. Telson longer than wide, distal excavation narrow, V-shaped ........... 27

27. Exopodite of U3 with long terminal spines (longer than marginal spines) . guernicae Notenboom, 1986

- Exopodite of U3 with short terminal spines (slightly shorter than marginal spines) ................. 28

28. Peduncle segment 5 and flagellum of A2 with few long setae ......................................... 29

- Peduncle segment 5 and flagellum of A2 densely armed with long setae ......................... 30

29. Sexual dimorphism of $\mathrm{Gn} 2$ weak

eborarius Notenboom, 1986

- Sexual dimorphism of Gn2 strong, female propodus much smaller than that of male jereanus Notenboom, 1986

30. Posterodistal angle of basis of P7 strongly produced. Mandible palp with 8-10 D-setae. Coxal plates 2-4 narrow .............. vasconiensis Notenboom, 1986

- Posterodistal angle of basis of P7 slightly overhanging. Mandible palp with 10-12 D-setae. Coxal plates 2-4 not conspicuously narrow

gorbeanus Notenboom, 1986

\section{ACKNOWLEDGEMENTS}

I wish to thank Remko Leys and Katja Hogendoorn for their efforts in collecting stygofauna in Galicia, leading to the discovery of the new Pseudoniphargus species. I am grateful to Prof. J. R. Holsinger and Prof. J. H. Stock, both read a draft of the manuscript and made improving comments.

Furthermore, I am indebted to the following institutions for the loan of type materials: Instituto de Zoologia "Dr. Augusto Nobre", Universidade do Porto, Portugal; Zoologisches Museum der Humboldt Universität, Berlin, D.D.R.; Zoologiska Institutionen, Avdelningen för Systematik, Lund, Sweden.
The investigations were supported by the Foundation for Fundamental Biological Research (BION), which is subsidized by the Netherlands Organization for the Advancement of Pure Research (ZWO).

\section{REFERENCES 。}

Afonso, O., 1983. Un Aselle phréatique nouveau du bassin du Mondego (Portugal) et des considérations sur les Asellides portugais (Crustacea, Isopoda, Asellidae). Publicaçōes Inst. Zool. Dr. Augusto Nobre, 178: 1-14.

- - 1984a. Un nouveau Synasellus (Crust., Isopoda, Asellidae) de la nappe phréatique littorale au sud du Douro. Publicações Inst. Zool. Dr. Augusto Nobre, 185: 1-12.

Isopoda, Asellidae) nouvelle espèce hypogée du bassin du Douro. Publicações Inst. Zool. Dr. Augusto Nobre, 187: 1-9.

Henry, J.-P., 1983. Biogéographie des Asellides souterrains de la Péninsule ibérique et du Midi de la France. Mém. Biospéol., 10: 193-198.

Mateus, A., 1980. La faune portugaise d'Amphipodes hypogés et sa comparaison à celle de la Roumanie. Trav. Inst. Spéol. Émile Racovitza, 19: 275-282.

Mateus, A. \& E. de Oliveira Mateus, 1978. Amphipoda hypogés du Portugal. Publicações Inst. Zool. Dr. Augusto Nobre, 142: 11-26.

Notenвoom, J., 1986. The species of the genus Pseudoniphargus Chevreux, 1901 (Amphipoda) from northern Spain. Bijdr. Dierk., 56 (1): 75-122.

- , 1987. Species of the genus Pseudoniphargus Chevreux, 1901 (Amphipoda) from the Betic Cordillera of southern Spain. Bijdr. Dierk., 57 (1): 87-150.

Schellenberg, A., 1943. Portugiesische SüsswasserAmphipoden. Mems. Estud. Mus. zool. Univ. Coimbra, 139: 1-7.

Stock, J. H., 1980. Regression model evolution as exemplified by the genus Pseudoniphargus (Amphipoda). Bijdr. Dierk., 50 (1): 105-144.

Stock, J. H., J. R. Holsinger, B. Sket \& Th. M. Iliffe, 1986. Two new species of Pseudoniphargus (Amphipoda), in Bermudian groundwaters. Zoologica Scr., 15 (3): 237-249. 